\title{
Parmigiano Reggiano cheese: evolution of cultivable and total lactic microflora and peptidase activities during manufacture and ripening
}

\author{
Juliano De DeA LINDNER ${ }^{1}$, Valentina BERNINI ${ }^{1}$, Angela DE LORENTIIS ${ }^{1}$, \\ Alberto PECORARI ${ }^{2}$, Erasmo NeVIANI ${ }^{1}$, Monica GATTI ${ }^{1 *}$ \\ ${ }^{1}$ Department of Genetics, Biology of Microorganisms, Anthropology, Evolution, \\ University of Parma, Parma, Italy \\ ${ }^{2}$ Consorzio del Formaggio Parmigiano-Reggiano, Reggio Emilia, Italy
}

\begin{abstract}
Parmigiano Reggiano is a Protected Designation of Origin, long-ripened cheese, made from cow's milk supplemented with natural whey starter, which thus contains a large microbial biodiversity. The aim of this study was to understand the population dynamics of the total lactic microflora throughout the manufacture and ripening of this cheese. Several approaches were combined to determine the quantitative changes in the different bacterial populations during 20 months of ripening of Parmigiano Reggiano cheeses from the same cheesemaking. Total and viable cells were enumerated after fluorescent labeling. Culturable bacteria were enumerated on different plate count agar media, including original media prepared from curd and ripened cheese. Six peptidase activities were quantified in curd and cheese samples free from cells. While the total bacterial cultivable population remained high and similar for the first six months, a decrease in viable starter lactic acid bacteria was observed during the first $48 \mathrm{~h}$. The non-starter lactic acid bacteria populations, initially present in low numbers, began to grow after the brining and remained at high levels (about $10^{7} \mathrm{CFU} \cdot \mathrm{g}^{-1}$ ) for at least 10 months. During ripening, a strong decrease in the total bacterial population and a marked increase in 4 out of 6 peptidase activities were observed. In the external and internal zones of Parmigiano Reggiano cheese different trends in microbial growth, cell autolysis and peptidase activity were observed. This study gives for the first time a global view of the possible contribution of total, viable, cultivable and lysed bacterial cells throughout the ripening of Parmigiano Reggiano cheese.
\end{abstract}

Parmigiano Reggiano cheese / ripening / lactic acid microflora / bacterial cell lysis / cell viability / peptidase activity

摘要 - 干酪制造和成熟期间乳酸菌菌群的可培养性和肽酶活性的评价。Parmigiano Reggiano 是一种受原产地名号保护 (PDO) 的产品, 是牛乳添加自然发酵形成的 乳清发酵剂而制成的长成熟期干酪, 因此所含的微生物种类繁多。本研究目的 是了解该干酪在整个制造和成熟期间乳酸菌菌群的动态变化。采用了不同的方 法对来自同一广家的成熟期为 20 个月的 Parmigiano Reggiano 干酪中不同的细 菌菌数进行了定量分析。用苂光标记法进行了总细胞和活细胞计数。在不同的 琼脂平板培养基上对最初凝乳和成熟干酪中的可培养细菌进行了计数。定量测 定了凝乳和干酪中的六种肽酶活性。研究发现总的可培养细菌数始终较高水平,

*Corresponding author (通讯作者): monica.gatti@unipr.it 
并且在前六个月细菌总数基本上相同,在最初的 48 小时发酵期内, 乳酸菌发酵剂的数量明显 降低。发酵初期, 非发酵剂乳酸菌数量较低, 但加盐渍后非发酵剂, 乳酸菌的数量持续上升, 至 少在 10 个月内持续增长并保持在较高水平 (约 $\left.10^{7} \mathrm{CFU} \cdot \mathrm{g}^{-1}\right)$ 。成熟过程中, 细菌总数显著下 降, 6 种肽酶中有 4 种活性显着增加。同时, 对 Parmigiano Reggiano 干酪的外部和内部区域 微生物生长的趋势, 细胞自溶和肽酶的活性也进行了研究。本文首次研究了总乳酸菌、活 菌, 可培养乳酸菌和溶解的菌体细胞对 Parmigiano Reggiano 干酪整个成熟期间的作用。

\title{
Parmigiano Reggiano 干酪 / 成熟 / 乳酸菌菌群 / 细菌细胞溶解 / 细胞活性 / 肽酶活性
}

\begin{abstract}
Résumé - Le Parmigiano Reggiano : évolution de la microflore lactique cultivable et totale et des activités peptidasiques pendant la fabrication et l'affinage. Le Parmigiano Reggiano est un fromage d'Appellation d'Origine Protégée à affinage long, fabriqué à partir de lait cru supplémenté d'un levain naturel issu du lactosérum. Ce fromage contient, en conséquence, une large biodiversité microbienne. L'objectif de cette étude était de comprendre la dynamique de population de la microflore lactique pendant la fabrication et l'affinage du Parmigiano Reggiano. Plusieurs approches ont été combinées pour déterminer l'évolution des différentes populations bactériennes dans ce fromage au cours de 20 mois d'affinage de fromages issus de la même série de fabrications. Le nombre de bactéries totales et viables a été mesuré après marquage fluorescent. Les bactéries cultivables ont été déterminées en utilisant différents milieux gélosés, incluant des milieux originaux préparés à partir de caillé et de fromage affiné. Six activités peptidasiques ont été quantifiées dans des échantillons de caillé et de fromages exempts de cellules bactériennes. La population de bactéries viables diminuait dans le caillé pendant les 48 premières heures, alors que la population totale de bactéries cultivables restait élevée et constante sur les six premiers mois d'affinage. Les populations de bactéries lactiques non levains, présentes initialement en faible nombre, commençaient à se développer dès le saumurage puis restaient à un niveau élevé (environ $10^{7} \mathrm{UFC} \cdot \mathrm{g}^{-1}$ ) pendant plus de 10 mois. Une forte chute de la population bactérienne totale était observée peandant l'affinage, accompagnée d'une hausse marquée de 4 activités peptidasiques. Dans les parties externes et internes du Parmigiano Reggiano, différentes tendances de croissance, d'autolyse et d'activité peptidasique étaient observées. Cette étude donne pour la première fois un aperçu global de la contribution possible des populations totales, viables, cultivables et lysées tout au long de l'affinage du Parmigiano Reggiano.
\end{abstract}

Parmigiano Reggiano / affinage / bactéries lactiques / lyse bactérienne / viabilité cellulaire / activité peptidasique

\section{INTRODUCTION}

Parmigiano Reggiano (PR) is a Protected Designation of Origin (PDO), hardtextured, cooked and long-ripened cheese. It is made following strict manufacturing procedures, from cow's milk supplemented with natural whey starter only (http://www. parmigiano-reggiano.it). Only unheated raw milk, obtained by mixing evening milk (partially skimmed by natural creaming) with full-cream milk of the following morning can be used. During the natural creaming the reduction of the bacteria ascending with the fat globules and the growth of the residual non-starter lactic acid bacteria (NSLAB) occur [28]. Natural whey starter consists of a culture of thermophilic lactic acid bacteria (SLAB) selected by cooking of the curd and by incubation of the sweet whey which results from each day's cheesemaking as it naturally cools down.

Other important technological characteristics are: the use of calf rennet, the cooking temperature of the curd (54$55{ }^{\circ} \mathrm{C}$ ), slow heat dissipation during lactic acid fermentation, whey drainage from the curd, and brining with $\mathrm{NaCl}$ and slow diffusion into the cheese, as well as a long ripening time of at least 12 months [25].

A very interesting recent study highlighted the effect of the curd cooking temperature on the viability of SLAB and 
NSLAB, cheese composition and ripening indices of an experimental semi-hard cheese [35]. The cooking temperature plays a key role in the acidification process in the first hours after PR cheesemaking [32]. Furthermore, the temperature at the end of cooking has been shown to influence the moisture content of cheese and to affect the acidification curves in the inner zone of the cheese, where slight variations in temperature can advance or delay the beginning of the lactic fermentation.

Microbiological features of PR have been studied by Coppola et al. [8,9], who isolated a great number of strains from a large amount of samples representative of the production and the earlier and advanced stages of ripening on traditional growth media. Recently, the diversity of the dominant lactic acid bacteria population in six samples of 12-month ripened Parmigiano Reggiano cheese was also investigated by a culture-independent approach [15]. However, the evolution of LAB during the ripening of the same cheesemaking, to our knowledge, has never been investigated.

During the ripening period, LAB contribute to cheese flavor development through several basic mechanisms that include carbohydrate fermentation, conversion of milk proteins into peptides and free amino acids, catabolism of amino acids into aroma compounds, hydrolysis of milk lipids into free fatty acids, and citrate catabolism [13]. In particular, for long-ripened cheeses such as PR, the proteolysis may be considered an essential multi-step biochemical event [14, 29].

Over the last few years, some LAB complex peptidase systems with different natures, specificities and localization have been characterized [6, 21, 26, 33, 38]. Residual enzymatic activity in cheese can be considered as the trace of the microbial ecosystem evolution during aging $[17,40]$. In a comprehensive study of the relationship between starter autol- ysis and the proteolytic enzyme complement released in Cheddar cheese, Sheehan et al. [34] found that differences in lactococcal starter autolysis influenced the proteolytic activities of the released enzymes during ripening. Moreover, in a recent study the positive impact of Lactobacillus helveticus autolysis on flavor precursor development in ripened Cheddar cheese has been demonstrated [19].

For many reasons, the study of lactic microflora and peptidase activities is important to understand the essential biochemical events during PR manufacture and ripening. In this work, a comprehensive sampling design allowed the analysis of this PDO cheese to be performed during its production and over 20 months of ripening. The SLAB and NSLAB cultivability and viability were assessed. Furthermore, in order to stress the role of microbial enzymes released after cellular lysis, the aminopeptidase and dipeptidylaminopeptidase activities in the extract of cheese, free from cells, were evaluated.

\section{MATERIALS AND METHODS}

\subsection{Cheesemaking}

With the aim of obtaining a suitable number of PR cheeses necessary for this study, a well-equipped factory able to guarantee the production of twin wheels was chosen. The milk and whey starter were held and processed in the same tanks and using a volume counter pump, the milk was distributed in equal volumes in the vats. The cheese was produced according to the PR production protocol (http://www. parmigiano-reggiano.it).

Natural whey starter was added to eight vats each containing $1040 \mathrm{~kg}$ of milk (510 kg of partially skimmed evening milk and $530 \mathrm{~kg}$ of whole morning milk) at $33 \mathrm{~g} \cdot \mathrm{L}^{-1}$, bringing the $\mathrm{pH}$ of the mixture to 6.20. After the cheesemaking and molding, the wheels were held for three days and 
frequently turned to enable complete whey drainage. Sixteen wheels were then salted by immersion in brine at $300 \mathrm{~g} \mathrm{NaCl} \cdot \mathrm{L}^{-1}$ for 23 days. Ripening was done in aging rooms with $85 \%$ relative humidity for 20 months.

\subsection{Dairy samples}

First of all, aliquots of the total mass of whey starter, raw milk and curd were sampled. Subsequently, for each of the following samples, curd 6, 12 and $48 \mathrm{~h}$ after extraction, salted cheese (1 month) and cheese at different stages of ripening $(2,3$, $4,6,8,10,12,16$ and 20 months) were used; the wheels were cut lengthwise along the vertical axis and a central cheese section $(1.0 \mathrm{~cm}$ thick) was obtained. Internal and external ( $0.5 \mathrm{~cm}$ from the cheese crust) portions were obtained from these cheese sections and grated before the analysis.

\subsection{Physico-chemical analyses}

The $\mathrm{pH}$ of samples was directly measured using a pH meter $(350 \mathrm{pH}$, Beckman Coulter, Fullerton, CA, USA).

Lactose, galactose, L-lactate and D-lactate were determined according to Careri et al. [4], by enzymatic assays in $\mathrm{g} \cdot \mathrm{L}^{-1}$ with Boehringer-Mannheim kits (Boehringer-Mannheim, Germany). Total lactate was obtained through the sum of L-lactate plus D-lactate.

Citrate, succinate, acetic acid and pyroglutamic acid were determined using a DAD 540 liquid chromatography system with a variable UV/visible wavelength (Kontron Instruments, Italy) and refractometric detectors (Refractive Index 475, Kontron Instruments, Italy). Analyses were performed using an Aminex HPX $87 \mathrm{H}$ cation exchange column (Bio-Rad Laboratories, CA, USA), and filtered and degassed $0.009 \mathrm{~N}$ reagent grade $\mathrm{H}_{2} \mathrm{SO}_{4}$ (Carlo Erba, Italy) as the mobile phase at a flow rate of $0.6 \mathrm{~mL} \cdot \mathrm{min}^{-1}$. Eluates were monitored at $215 \mathrm{~nm}$. The calibration curves were obtained by preparing a standard mix of the organic acids (Sigma, USA). The resulting peaks areas were calculated for duplicate $25-\mu \mathrm{L}$ injections and plotted against concentration using the software Kromasystem 2000 (Kontron Instruments, Italy).

Each assay was carried out in duplicate and average values expressed in $\mathrm{g} \cdot 100 \mathrm{~g}^{-1}$ for the lactose, galactose, L-lactate, D-lactate, citrate, succinate, and acetic and pyroglutamic acid concentration during PR manufacturing and ripening. The estimated error for the enzymatic assays was less than 5\% and for the chromatographic assays it was less than $3 \%$.

\subsection{Microbiological analyses}

\subsubsection{Media and growth conditions}

Whey starter and milk were serially diluted tenfold in $0.05 \mathrm{~mol} \cdot \mathrm{L}^{-1}$ sodium citrate (Sigma, Italy) buffer, $\mathrm{pH} 7.5$, while $10 \mathrm{~g}$ of curd and $10 \mathrm{~g}$ of the internal or external cheese samples were first homogenized for $3 \mathrm{~min}$ in a blender (Stomacher 400, Seward, UK) with sodium citrate before being serially diluted. In order to recover the cultivable bacterial population, the following media and temperature/time conditions of incubation were used: MRS agar pH 5.4 (Oxoid, Italy) at $42{ }^{\circ} \mathrm{C}$ for $48 \mathrm{~h}$ and $25^{\circ} \mathrm{C}$ for $72 \mathrm{~h}$ to facilitate, respectively, the growth of thermophilic and mesophilic lactobacilli; M17-SSW [12] at $42{ }^{\circ} \mathrm{C}$ for $42 \mathrm{~h}$ to count streptococci, and $25{ }^{\circ} \mathrm{C}$ for $72 \mathrm{~h}$ to count lactococci; and whey agar medium (WAM) [18] at $42{ }^{\circ} \mathrm{C}$ for $48 \mathrm{~h}$ to facilitate the growth of the strains arising from natural whey starter. Moreover, curd agar medium (CURDAM) [22] and cheese agar medium (CAM) [10, 22], which are media mainly composed of grated curd and ripened cheese, respectively, were used at $42{ }^{\circ} \mathrm{C}$ for $72 \mathrm{~h}$ to select low nutritional-demanding LAB. 
The media were all incubated under anaerobic conditions. The microbial counts were carried out in duplicate and the standard deviation of mean values was calculated. The estimated error was less than $10 \%$.

\subsubsection{Cell viability count}

Cell viability was directly checked using a LIVE/DEAD BacLight Bacterial Viability Kit (Molecular Probes Inc., Eugene, USA) and an epifluorescence microscope (Nikon 80i, Tokyo, Japan) [16]. Curd and cheese samples were diluted as previously described, centrifuged $(8000 \times g, 10 \mathrm{~min}$, $4{ }^{\circ} \mathrm{C}$ ) and pelleted. The resulting pellet was diluted in $1 \mathrm{~mL}$ of sterile water and treated with $0.7 \mu \mathrm{L}$ of Syto 9 stain and $1 \mu \mathrm{L}$ of propidium iodide stain. Direct counts of total, viable and unviable bacterial populations were evaluated using a Thoma chamber (Brand, Germany). Each sample was prepared and counted in duplicate and average values were calculated. The estimated error was about $3 \%$ [16].

\subsection{Determination of peptidase activities}

Sample extracts were prepared according to Gatti et al. [17]. A dialysis step was included to eliminate any low-molecularweight substances such as salts which could interfere with the successive reactions. The sample suspension obtained after $24 \mathrm{~h}$ of dialysis in tube-shaped cellulose (Spectra/por, Spectrum Laboratories Inc., USA), with a cutoff of $3000 \mathrm{~g} \cdot \mathrm{mol}^{-1}$, was centrifuged $\left(10000 \times g, 10 \mathrm{~min}, 4^{\circ} \mathrm{C}\right)$, filtered through a cellulose acetate membrane with $0.22 \mu \mathrm{m}$ pore size (Sartorius, Italy) and incubated with $0.650 \mathrm{mmol} \cdot \mathrm{L}^{-1}$ solutions of amino acid $\beta$-naphthylamide $(\beta N A)$ derivates (Bachem Feinchemikalien AG, Switzerland) and $0.05 \mathrm{~mol} \cdot \mathrm{L}^{-1}$ phosphate buffer $\mathrm{pH} 7.0$ at $40{ }^{\circ} \mathrm{C}$ in different amounts for different times: Lys- $\beta \mathrm{NA}$, Arg- $\beta \mathrm{NA}$, Leu- $\beta \mathrm{NA}: 50 \mu \mathrm{L}$ of dialyzed suspension, $125 \mu \mathrm{L}$ of $\beta \mathrm{NA}$ substrate, $125 \mu \mathrm{L}$ of phosphate buffer and $200 \mu \mathrm{L}$ of bidistilled water for $1 \mathrm{~h}$ for the first two substrates and $3 \mathrm{~h}$ for the third one; Pro- $\beta$ NA: $300 \mu \mathrm{L}$ of dialyzed suspension, $100 \mu \mathrm{L}$ of $\beta \mathrm{NA}$ substrate and $100 \mu \mathrm{L}$ of phosphate buffer for $24 \mathrm{~h}$; Glu- $\beta$ NA: $350 \mu \mathrm{L}$ of dialyzed suspension, $75 \mu \mathrm{L}$ of $\beta \mathrm{NA}$ substrate and $75 \mu \mathrm{L}$ of phosphate buffer for $24 \mathrm{~h}$; Phe-Pro- $\beta \mathrm{NA}$ : $50 \mu \mathrm{L}$ of dialyzed suspension, $125 \mu \mathrm{L}$ of $\beta \mathrm{NA}$ substrate, and $325 \mu \mathrm{L}$ of bidistilled water for $1 \mathrm{~h}$. The reaction was stopped by the addition of $250 \mu \mathrm{L}$ of $2.0 \mathrm{~mol} \cdot \mathrm{L}^{-1} \mathrm{HCl}$. The degree of hydrolysis was determined by measuring the colored product of an azocopulation reaction by reading spectrophotometrically at $580 \mathrm{~nm}\left(\mathrm{~A}_{580 \mathrm{~nm}}\right)$ according to Boquien et al. [1]. Each assay was carried out in duplicate and the average values were calculated. The estimated error was less than $1.5 \%$. The arbitrary unit of enzyme activity (EA) was defined as the number of micromoles of $\beta$-naphthylamide released in one hour in one $\mathrm{mL}$ of each sample.

\section{RESULTS AND DISCUSSION}

\subsection{Chemical analyses}

Organic acids are important indicators of biochemical metabolic processes occurring during the ripening of cheese. The results obtained from the evaluation of organic acids can be used as a reflection of the bacterial metabolism and fermentation which characterize PR cheese [27].

Table I shows that at the beginning of the cheesemaking, lactose and galactose were totally consumed by thermophilic SLAB. At the same time, an expected increase in lactate was observed. Lactate produced from lactose was in agreement with other authors, who described it as the most abundant organic acid in Parmigiano Reggiano cheese, ranging from 1.30 
Table I. $\mathrm{pH}$ and mean values in $\mathrm{g} \cdot 100 \mathrm{~g}^{-1}$ obtained after duplicate assays for the concentration of lactose, galactose, L-lactate, D-lactate, lactate, citrate, succinate, acetic and pyroglutamic acid during Parmigiano Reggiano manufacturing and ripening. Total lactate was obtained through the sum of L-lactate plus D-lactate.

\begin{tabular}{|c|c|c|c|c|c|c|c|c|c|c|}
\hline & $\overline{\mathrm{pH}}$ & Lactose & alactose & $\begin{array}{c}\text { L- } \\
\text { Lactate }\end{array}$ & $\begin{array}{c}\text { D- } \\
\text { Lactate }\end{array}$ & Lactate & Citrate & uccinat & $\begin{array}{c}\text { Acetic } \\
\text { acid }\end{array}$ & $\begin{array}{l}\text { oglutam } \\
\text { acid }\end{array}$ \\
\hline Milk & 6.73 & 4.81 & - & - & - & - & 0.16 & - & - & - \\
\hline Whey starter & 3.25 & - & - & - & - & - & - & - & - & - \\
\hline $\begin{array}{l}\text { Curd at vat } \\
\text { extraction }\end{array}$ & 6.00 & 1.36 & 0.09 & 0.10 & 0.09 & 0.19 & - & - & - & - \\
\hline Curd $6 \mathrm{~h}$ & 5.75 & 0.40 & 0.39 & 0.22 & 0.20 & 0.43 & - & - & - & - \\
\hline Curd $12 \mathrm{~h}$ & 5.57 & 0.15 & 0.56 & 0.24 & 0.24 & 0.48 & - & - & - & - \\
\hline Curd $48 \mathrm{~h}$ & 4.36 & 0 & 0 & 0.47 & 0.58 & 1.05 & 0.05 & 0.03 & 0.04 & - \\
\hline $\begin{array}{l}\text { Salted cheese } \\
\text { (1 month) }\end{array}$ & 5.35 & 0 & 0 & 0.77 & 0.61 & 1.38 & - & - & - & - \\
\hline Cheese 2 months & 5.36 & 0 & 0 & 0.73 & 0.57 & 1.30 & - & - & - & - \\
\hline Cheese 3 months & 5.37 & 0 & 0 & 0.72 & 0.67 & 1.39 & - & - & - & - \\
\hline Cheese 4 months & 5.36 & 0 & 0 & 0.85 & 0.60 & 1.45 & - & - & - & - \\
\hline Cheese 6 months & 5.33 & 0 & 0 & 0.73 & 0.69 & 1.42 & 0.05 & 0.04 & 0.09 & 0.18 \\
\hline Cheese 8 months & 5.41 & 0 & 0 & 0.72 & 0.62 & 1.34 & - & - & - & - \\
\hline Cheese 10 months & 5.37 & 0 & 0 & 0.74 & 0.63 & 1.37 & - & - & - & - \\
\hline Cheese 12 months & 5.42 & 0 & 0 & 0.73 & 0.63 & 1.36 & - & - & - & - \\
\hline Cheese 16 months & 5.41 & 0 & 0 & 0.69 & 0.63 & 1.32 & - & - & - & - \\
\hline Cheese 20 months & 5.41 & 0 & 0 & 0.75 & 0.68 & 1.43 & 0.05 & 0.05 & 0.12 & 0.51 \\
\hline
\end{tabular}

to $1.45 \mathrm{~g} \cdot 100 \mathrm{~g}^{-1}[4,28]$. The concentrations of L- and D-lactic acid were approximately the same (L:D ratio approx. 1:1). In fact, both optical isomers are produced from lactose by the thermophilic LAB component of the natural starter. The values for citrate and succinate are in agreement with the results described by Careri et al. [4], but disagree with Coppola et al. [8], who observed a gradual decrease in citrate concentration during aging. During our PR cheesemaking, citrate was apparently not used as an energy source by facultative heterofermentative $\mathrm{LAB}$, even though many of them have the potential to metabolize it as well when fermentable sugars are present [7]. Our findings suggest that the growth of the microorganisms after the start of the ripening was probably not connected to their ability to utilize citrate as a source of energy. The acetic acid values found are in agreement with previous reports [4]. Pyroglutamic acid is related to the age of PR [27]. The association of glutamic acid with pyroglutamic acid cyclase activity was demonstrated for thermophilic lactic species. The cyclization of glutamic acid in pyroglutamic acid was proposed by Mucchetti et al. [24] as a ripening marker in long-ripened cooked cheese. Our results for this organic acid support this hypothesis.

\subsection{Microbial counts and growth trends}

LAB cultivability was evaluated during PR manufacturing and ripening. Figures $1 \mathrm{a}$ and $1 \mathrm{~b}$ show the growth trends of cultivable populations in MRS 5.4, M17SSW, WAM, CURDAM and CAM for both internal and external zones of the 


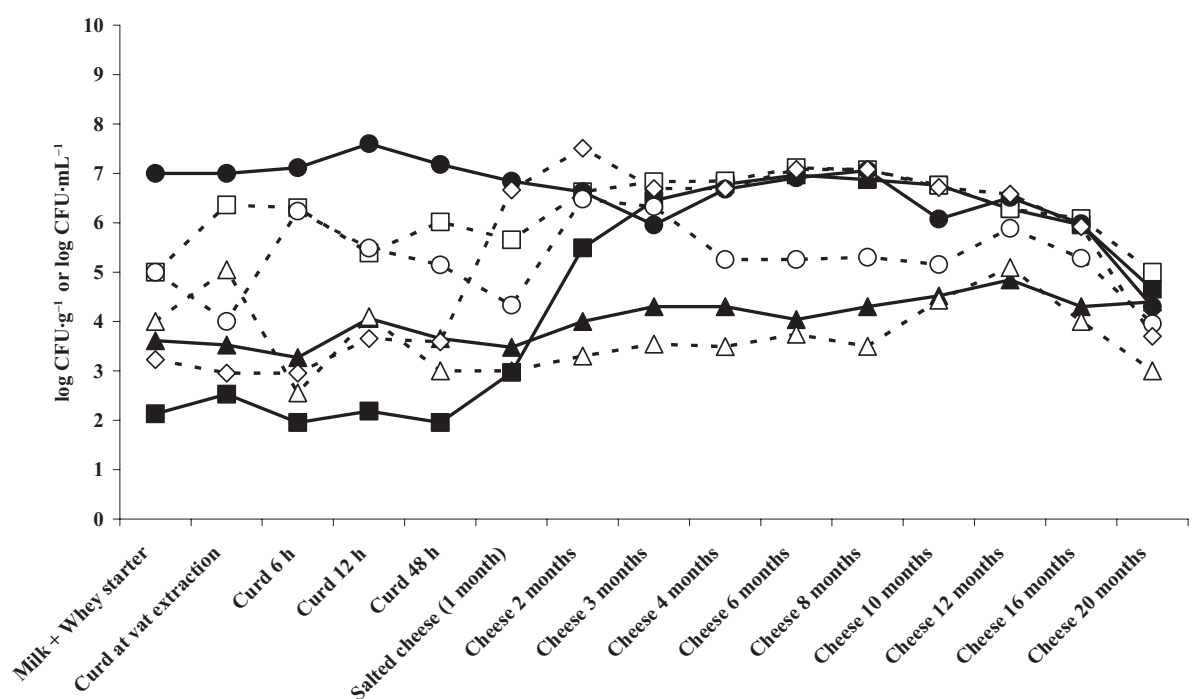

(a)

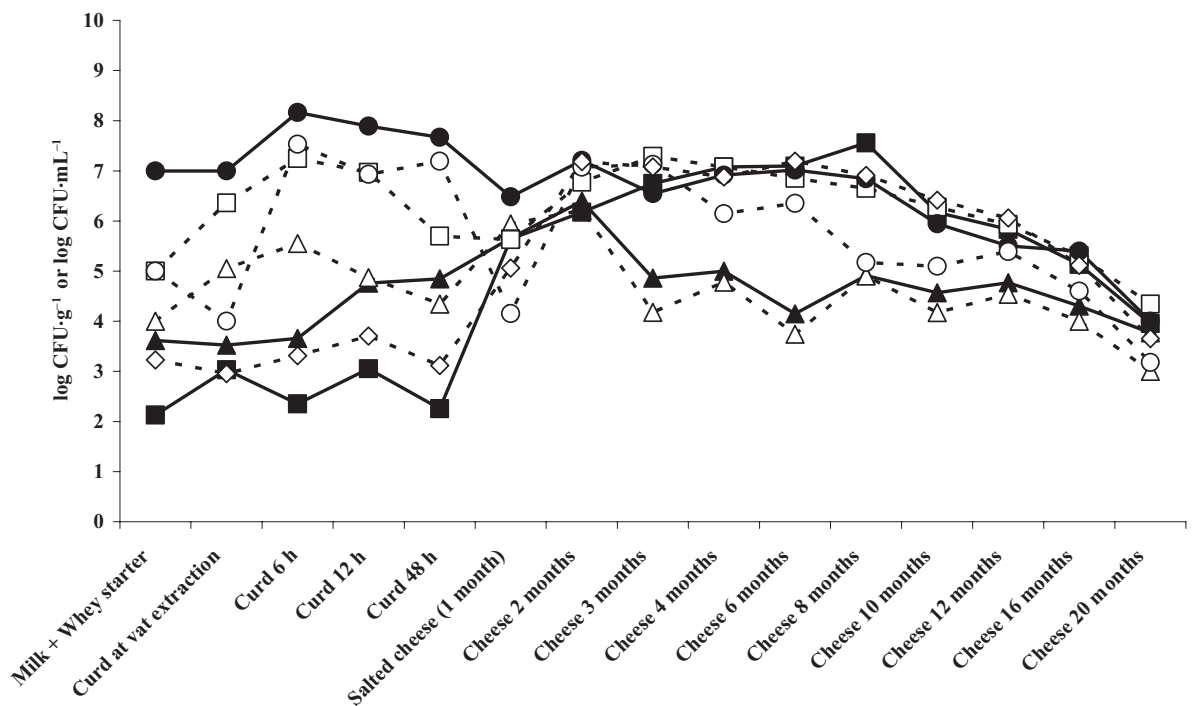

(b)

Figure 1. Evolution of the cultivable population, expressed as $\log \mathrm{CFU} \cdot \mathrm{g}^{-1}$ or $\log \mathrm{CFU} \cdot \mathrm{mL}^{-1}$, during different steps of Parmigiano Reggiano cheese manufacturing and ripening. Solid line $\mathbf{\Delta}$ : M17SSW $25{ }^{\circ} \mathrm{C}$; dotted line $\triangle$ : M17-SSW $42{ }^{\circ} \mathrm{C}$; solid line $\mathbf{m}$ : MRS $5.425^{\circ} \mathrm{C}$; dotted line $\square$ : MRS $5.442{ }^{\circ} \mathrm{C}$; solid line $\bullet$ : WAM $42{ }^{\circ} \mathrm{C}$; dotted line o: CURDAM $42{ }^{\circ} \mathrm{C}$; dotted line $\diamond$ : CAM $42{ }^{\circ} \mathrm{C}$. a: Internal zone; b: external zone. 
cheeses, respectively. The microbiological counts for the whey starter were estimated as $7.7 \times 10^{4}$ colony-forming units $(\mathrm{CFU}) \cdot \mathrm{mL}^{-1}$ in $\mathrm{M} 17-\mathrm{SSW}$ incubated at $42^{\circ} \mathrm{C}, 1.0 \times 10^{7} \mathrm{CFU} \cdot \mathrm{mL}^{-1}$ in MRS 5.4 $42{ }^{\circ} \mathrm{C}, 3.4 \times 10^{8} \mathrm{CFU} \cdot \mathrm{mL}^{-1}$ in WAM, $1.0 \times 10^{7} \mathrm{CFU} \cdot \mathrm{mL}^{-1}$ in CURDAM and $10 \mathrm{CFU} \cdot \mathrm{mL}^{-1}$ in CAM. The microbiological counts for milk were estimated as $4.1 \times 10^{3} \mathrm{CFU} \cdot \mathrm{mL}^{-1}$ in M17-SSW incubated at $25^{\circ} \mathrm{C}, 7.8 \times 10^{3} \mathrm{CFU} \cdot \mathrm{mL}^{-1}$ in M17-SSW $25^{\circ} \mathrm{C}, 1.4 \times 10^{2} \mathrm{CFU} \cdot \mathrm{mL}^{-1}$ in MRS $5.425{ }^{\circ} \mathrm{C}, 90 \mathrm{CFU} \cdot \mathrm{mL}^{-1}$ in MRS $5.442{ }^{\circ} \mathrm{C}, 2.7 \times 10^{2} \mathrm{CFU} \cdot \mathrm{mL}^{-1}$ in WAM, $1.5 \times 10^{3} \mathrm{CFU} \cdot \mathrm{mL}^{-1}$ in CURDAM and $1.7 \times 10^{3} \mathrm{CFU} \cdot \mathrm{mL}^{-1}$ in CAM.

Figures $1 \mathrm{a}$ and $1 \mathrm{~b}$ show that the total microbial cultivable population remained high and similar for the first six months. After six months, a progressive decrease was observed. The evolution of the microbial counts in the five growth media was different for the first $48 \mathrm{~h}$, and split into two groups after four months: the highest counts were in WAM, MRS $5.442{ }^{\circ} \mathrm{C}$ and CAM; the lowest in M17-SSW $25^{\circ} \mathrm{C}$ and $42{ }^{\circ} \mathrm{C}$. In particular, when three months of ripening were reached in the internal and external zones, the values of microbial counts on MRS 5.4, WAM and CAM result overlapped and remained comparable until the end of ripening. After 9-10 months of ripening a decrease in the number of cultivable bacteria was observed. Counts in CURDAM were low (in the order of $10^{-1}$ to $10^{-2}$ ), and the lowest counts were observed for the streptococcal and lactococcal populations, evaluated in M17-SSW agar, respectively, at 42 and $25^{\circ} \mathrm{C}$. We hypothesize that the majority of the microbial populations found in cheese after four months of ripening were not able to metabolize lactose, present in M17-SSW and CURDAM media as a carbon source.

Microbial counts in WAM confirmed that after the addition of whey starter, because of the temperatures used during production in the first $48 \mathrm{~h}$, the thermophilic microflora (SLAB) became dominant in respect to the mesophilic microflora (Figs. 1a and $1 b)$. In this phase, the nutritionally demanding microorganisms found in WAM had the best conditions for growth. WAM attempts to reproduce the natural composition of the whey; it supports the original population from the whey starter and can be considered the growth medium that best suits their growth. Different microbial counts were detected using WAM for the internal and external 6-h curd, suggesting that the early decrease in temperature in the external zone of the wheel could have favored the growth of SLAB.

Microorganisms cultivated at $25{ }^{\circ} \mathrm{C}$ in MRS 5.4 and at $42{ }^{\circ} \mathrm{C}$ in CAM were unable to grow in the first $48 \mathrm{~h}$. However, in the advanced phase of ripening (Figs. 1a and $1 \mathrm{~b}$ ), they demonstrated the ability to use alternative potential energy sources and also to metabolize carbon sources other than lactose and citrate. These microflora were probably NSLAB originating from milk, as observed in other hard cooked cheeses such as Swiss Gruyère [5]. Generally, only a few strains survive the processing conditions and grow during ripening [5].

The number of SLAB commonly exceeds $10^{9} \mathrm{CFU} \cdot \mathrm{g}^{-1}$ in many young semihard and hard ripened cheeses [2]. At the same time, NSLAB populations occur in numbers of about $10^{2} \mathrm{CFU} \cdot \mathrm{g}^{-1}$ and begin to grow and eventually plateau at cell densities of $10^{7}-10^{9} \mathrm{CFU} \cdot \mathrm{g}^{-1}$ after several months of aging [2]. Using the plate count agar technique, we found similar values only for NSLAB, whereas the value of SLAB, at the beginning of ripening, was more than $1 \mathrm{log}$ less than the population generally found [2]. This difference may be due to the intrinsic limits of traditional agar-based and culture-dependent methods applied to estimating the SLAB arising from a natural whey starter [16]. Moreover, we found that in advanced phases of PR ripening (over 12 months), presumptive 


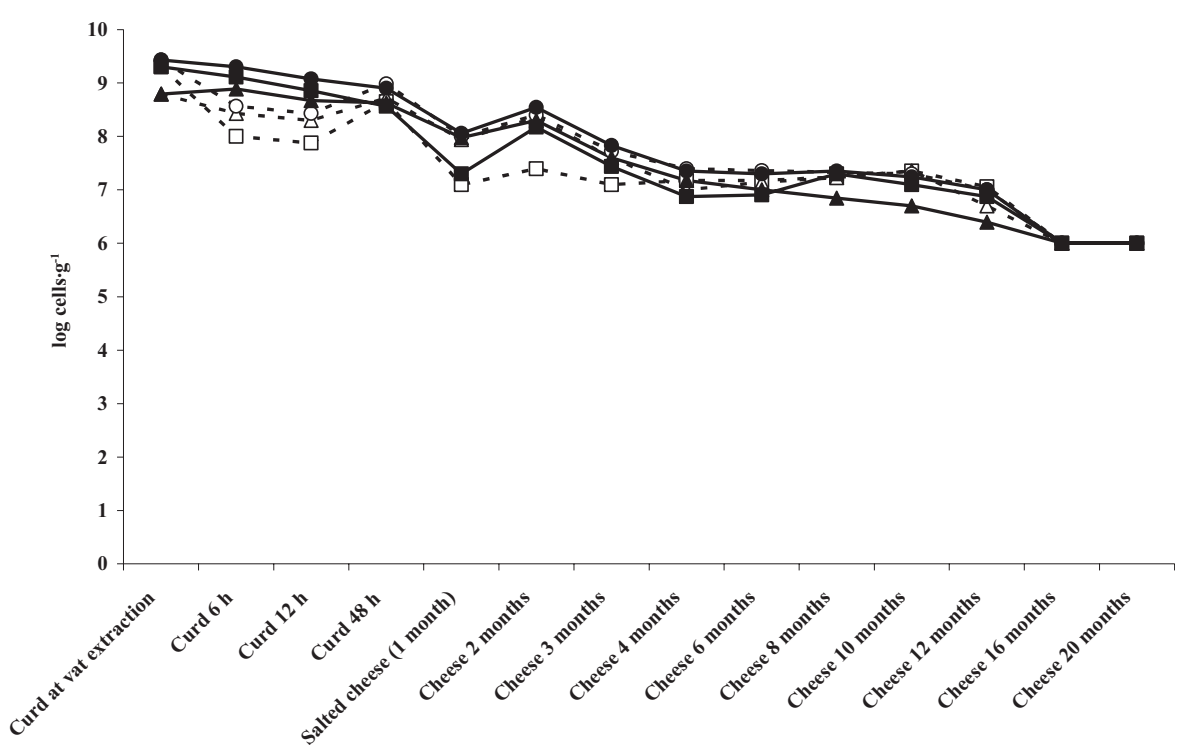

Figure 2. Evolution of the viable $\mathbf{\square}$, not viable $\boldsymbol{\Delta}$ and total population $\bullet$, expressed as log cells $\cdot \mathrm{g}^{-1}$, in internal (dotted line) and external (solid line) zones, during different steps of Parmigiano Reggiano cheese manufacturing and ripening.

mesophilic lactobacilli counts were higher than presumptive lactococci in both cheese portions.

\subsection{Cell viability counts}

Cell viability counts using a Bacterial Viability Kit allowed the determination of the viable (undamaged cell membrane) and the unviable (damaged cell membrane) bacteria. The sum of viable and unviable counts gives an indication of the direct total population. Total microbial counts using the cell viability method gives additional information compared with classical plate counts, where there is the influence of adaptability, choice of nutritional substrate and incubation parameters. Figures 1 and 2 show that cultivable populations were always lower than total direct population counts, especially at the beginning of cheese production. During ripening, the culture medium CAM supported the recovery of the total cultivable population, as demonstrated by an overlap of both plate and direct count results. In the first $12 \mathrm{~h}$ of manufacture, viable, unviable and total populations were higher in the external portion of cheese than in the internal portion (Fig. 2). In particular, viable cells in the external portion of the curd were one logarithm higher than those in the internal portion.

The assessment of total counts highlighted the induction of bacterial lysis. During aging, the conditions prevailing in the cheese matrix limit the preservation of cell viability [2]. The absence of residual lactose and galactose, high levels of $\mathrm{NaCl}$, low $\mathrm{pH}$ and the drop in temperature contribute to cell autolysis, which results in the release of intracellular enzymes and other components into the cheese matrix. In the one-month cheese sample, a reduction in the number of total cells was observed both in the external and internal portions. Interestingly, between the first and the second months an increase in the total population, 


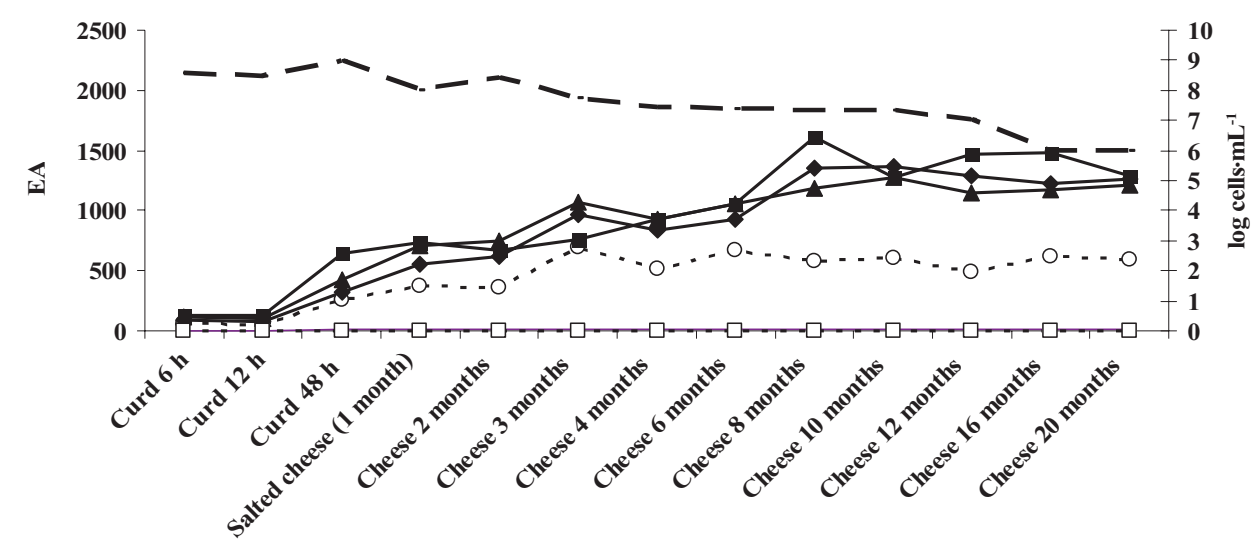

(a)

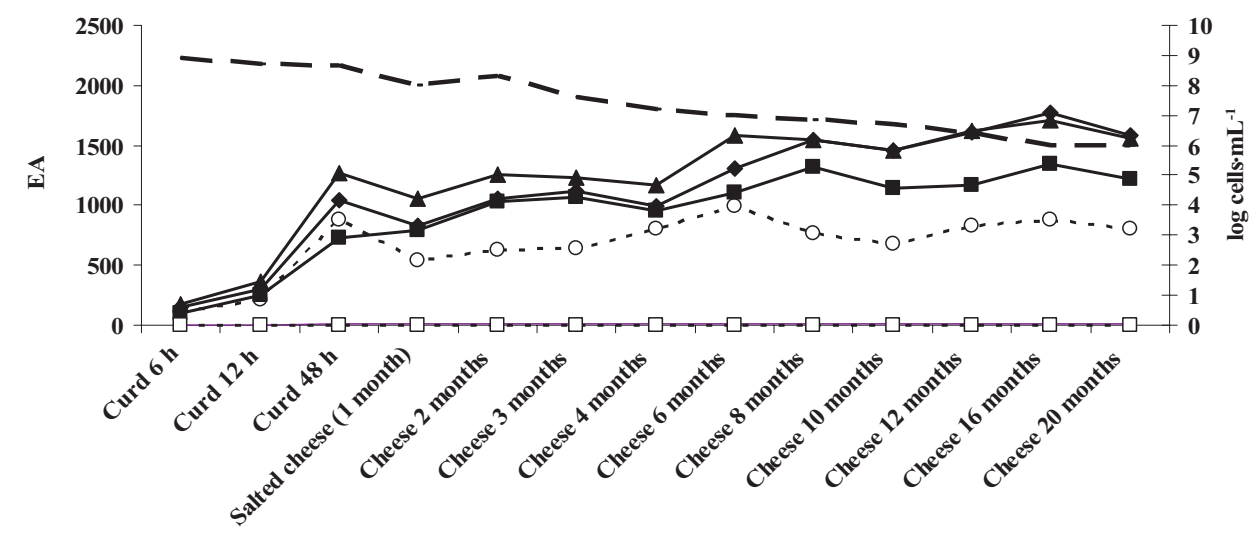

(b)

Figure 3. Evolution of aminopeptidase activities expressed as EA and total population expressed as $\log$ cells $\cdot \mathrm{g}^{-1}$ (secondary axis - dashed line), during different steps of Parmigiano Reggiano cheese manufacturing and ripening. Solid line $\mathbf{m}$ : PepX; solid line $\mathbf{\Delta}$ : PepN; solid line $\bullet$ : PepC; solid line $\bullet$ : PepI; dotted line $\circ$ : PepL; dotted line $\square$ : PepA. a: Internal zone; b: external zone.

especially in the external portion, was observed. After the second month of ripening, a continuous and gradual decrease in viable counts was observed until the end of ripening (Fig. 2).

\subsection{Enzymatic activity}

Biochemical transformation of the curd proteins and peptides during cheese ripen- ing is partly due to the cytoplasmatic enzymes released after cellular lysis, in particular SLAB autolysis [23, 39]. The peptidases released are responsible for the formation of water-soluble peptides and free amino acids [2,33]. Moreover, $\mathrm{LAB}$, in particular NSLAB, can utilize free amino acids for protein synthesis, generation of metabolic energy and recycling of reduced cofactors, which are connected 
with cheese flavor formation [6, 36, 41]. Amino acid catabolism involves a wide range of both general and specific regulators and shows significant differences among LAB [11].

The aminopeptidase activities tested in this work were those frequently found in LAB and capable of hydrolyzing the following six different substrates: broadspecificity aminopeptidase $\mathrm{N}(\mathrm{PepN})$ and $\mathrm{C}$ (PepC) activities were determined using Lys- $\beta$ NA and Arg- $\beta$ NA, respectively, proline aminopeptidase (PepI) activity using Pro- $\beta$ NA, glutamyl aminopeptidase A (PepA) activity using Glu- $\beta$ NA, peptidase with high specificity for leucine and alanine (PepL) using Leu- $\beta$ NA, and activity of the X-prolyl dipeptidyl aminopeptidase (PepX) was determined using PhePro- $\beta$ NA $[6,33]$. The enzymatic activity values detected in the cheese extract free from cells are shown in Figures $3 a$ and $3 b$ for the internal and external zones of the cheese. These results reflect an enzymatic activity due only to cytoplasmatic enzymes released after bacterial lysis.

PepC, PepN, PepX and PepL activities were higher in the external zone of cheese (Fig. 3b) than in the internal zone (Fig. 3a), especially during the first six months of aging. In both zones, PepA and PepI activities were very low, in contrast to the high quantity of proline and glutamic acid usually found in free form at the end of ripening [4,31]. In general, glutamic acid is the main amino acid detected in cheeses produced with a thermophilic starter and cooked with a temperature gradient such as PR [4], Swiss cheese [30], Gruyère [3] and Emmental and Bergkäse [20]. This apparent contradiction might be explained in different ways: (i) Glu can be liberated by broad-specificity aminopeptidase like PepC [6]; (ii) the hydrolytic activity towards Glu and Pro is low but always present during ripening; (iii) Glu and Pro are highly present in milk proteins [37]; and (iv) Pro is not further converted into degraded molecules and gradually increases in cheese [11].

A significant increase in EA was detected in the first $48 \mathrm{~h}$ of manufacture. These results are in agreement with the decrease in total counts observed, in particular in the cheese internal zone. A second stage of EA increase was observed for the internal zone during the $6^{\text {th }}$ and $8^{\text {th }}$ months (Fig. 3a) and for the external zone during the $4^{\text {th }}$ and $6^{\text {th }}$ months (Fig. 3b). Over the 20 months of ripening, similar quantitative ascending trends in the hydrolysis of specific substrates were observed for the internal and external zones of the cheese.

\section{CONCLUSION}

The Parmigiano Reggiano cheese ripening process is a very complex biochemical event. Technological parameters determine the specific microbial selection in the different stages of cheesemaking and ripening and even in the different cheese zones. Our results show that the microbial populations present in curd and in cheese can play different roles in the subsequent phases of ripening and can interact by overlapping their metabolic pathways. For example, the SLAB are involved not only in lactose depletion and curd acidification, but also in the production of a considerable amount of intracellular aminopeptidases released as a consequence of bacterial lysis, which are active during the whole ripening.

Regarding NSLAB, they remain viable for a long time during cheese ripening. They seem to adapt better to cheese than SLAB and are able to survive and grow even in the absence of lactose. The technological role of this secondary microflora should be investigated in greater depth.

The microbial dynamics, the identification of all microbial species, the infraspecies biodiversity and their interactions during PR cheesemaking and ripening are not still completely clarified. 
This gap should be filled to understand better and protect the origin, the tradition and the quality of this PDO cheese.

Acknowledgements: This work was partially supported by the Emilia Romagna Region (LR28/98), Bologna, Italy, Project "SMEPR Studio e modellazione degli aspetti enzimatici legati alla stagionatura del formaggio Parmigiano-Reggiano". The authors thank the Consorzio Parmigiano Reggiano, Reggio Emilia, Italy and CRPA Spa, Reggio Emilia, Italy, for their organizational and technical contributions. The authors are grateful to Dr. R. Ghiglietti (CRA-FLC Lodi, Italy) for the organic acid determination.

\section{REFERENCES}

[1] Boquien C.Y., Corrieu G., Desmazeaud M.J., Enzymatic methods for determining populations of Streptococcus cremoris AM2 and Leuconostoc lactis CNRZ 1091 in pure and mixed cultures, Appl. Microbiol. Biotech. 30 (1989) 402-407.

[2] Broadbent J.R., Steele J.L., Cheese flavor and the genomics of lactic acid bacteria, ASM News 71 (2005) 121-125.

[3] Bütikofer U., Fuchs D., Development of free amino acids in Appenzeller, Emmentaler, Gruyère, Raclette, Sbrinz and Tilsiter cheese, Lait 77 (1997) 91-100.

[4] Careri M., Spagnoli S., Panari G., Zannoni M., Barbieri G., Chemical parameters of the non-volatile fraction of ripened ParmigianoReggiano cheese, Int. Dairy J. 6 (1996) $147-$ 155.

[5] Casey M.G., Häni J.P., Gruskovnjak J., Schaeren W., Wechsler D., Characterisation of the non-starter lactic acid bacteria (NSLAB) of Gruyère PDO cheese, Lait 86 (2006) 407-414.

[6] Christensen J.E., Dudley E.G., Pederson J.A., Steel J.L., Peptidases and amino acid catabolism in lactic acid bacteria, Antonie van Leeuwenhoek 76 (1999) 217-249.

[7] Cogan T.M., Beresford T.P., Steele J., Broadbent J., Shah N.P., Ustunol Z., Invited review: Advances in starter cultures and cultured foods, J. Dairy Sci. 90 (2007) 40054021.

[8] Coppola R., Nanni M., Iorizzo M., Sorrentino A., Sorrentino E., Chiavari C., Grazia L., Microbiological characteristics of Parmigiano Reggiano cheese during the cheesemaking and the first months of the ripening, Lait 80 (2000) 479-490.

[9] Coppola R., Nanni M., Iorizzo M., Sorrentino A., Sorrentino E., Grazia L., Survey of lactic acid bacteria isolated during the advance stages of the ripening of Parmigiano Reggiano cheese, J. Dairy Res. 64 (1997) 305-310.

[10] De Dea Lindner J., Traditional and innovative approaches to evaluate microbial contribution in long ripened fermented foods: the case of Parmigiano Reggiano cheese, Ph.D. thesis, University of Parma, Italy, 2008.

[11] Fernández M., Zúñiga M., Amino acid catabolic pathways of lactic acid bacteria, Crit. Rev. Microbiol. 32 (2006) 155-183.

[12] Fornasari M.E., Rossetti L., Carminati D., Giraffa G., Cultivability of Streptococcus thermophilus in Grana Padano cheese whey starters, FEMS Microbiol. Lett. 257 (2006) 139-144.

[13] Fox P.F., Wallace J.M., Formation of flavour compounds in cheese, Adv. Appl. Microbiol. 45 (1997) 17-85.

[14] Fox P.F., Wallace J.M., Morgan S., Lynch C.M., Niland E.J., Tobin J., Acceleration of cheese ripening, Antonie van Leeuwenhoek 70 (1996) 271-297.

[15] Gala E., Landi S., Solieri L., Nocetti M., Pulvirenti A., Giudici P., Diversity of lactic acid bacteria population in ripened Parmigiano Reggiano cheese, Int. J. Food Microbiol. 125 (2008) 347-351.

[16] Gatti M., Bernini V., Lazzi C., Neviani E., Fluorescence microscopy for studying the viability of micro-organisms in natural whey starters, Lett. Appl. Microbiol 42 (2006) 338-343.

[17] Gatti M., Fornasari M.E., Mucchetti G., Addeo F., Neviani E., Presence of peptidase activities in different varieties of cheese, Lett. Appl. Microbiol. 28 (1999) 368-372.

[18] Gatti M., Lazzi C., Rossetti L., Mucchetti G., Neviani, E., Biodiversity in Lactobacillus helveticus strains present in natural whey starter used for Parmigiano Reggiano cheese, J. Appl. Microbiol. 95 (2003) 463-470.

[19] Hannon J.A., Kilcawley K.N., Wilkinson M.G., Delahunty C.M., Beresford T.P., Flavour precursor development in Cheddar cheese due to lactococcal starters and the presence and lysis of Lactobacillus helveticus, Int. Dairy J. 17 (2007) 316-327.

[20] Krause I., Bockhardt A., Klostermeyer H., Characterization of cheese ripening by free amino acids and biogenic amines and influence of bactofugation and heat-treatment of milk, Lait 77 (1997) 101-108. 
[21] Kunji E.R.S., Mierau I., Hagting A., Poolman B., Konings W.N., The proteolytic system of lactic acid bacteria, Antonie Van Leeuwenhoek 70 (1996) 187-221.

[22] Lazzi C., Gatti M., Bernini V., De Dea Lindner J., Neviani E., Impiego di nuovi terreni colturali a base di cagliata e di formaggio per il recupero e la differenziazione della microflora caratteristica di formaggi a lunga stagionatura, Sci. Tecn. Latt.-Cas. 58 (2007) 55-69.

[23] Lortal S., Chapot-Chartier M.P., Role, mechanisms and control of lactic acid bacteria lysis in cheese, Int. Dairy J. 15 (2005) 857871.

[24] Mucchetti G., Locci F., Gatti M., Neviani E., Addeo F., Dossena A., Marchelli R., Pyroglutamic acid in cheese: presence, origin, and correlation with ripening time of Grana Padano cheese, J. Dairy Sci. 83 (2000) 659-665.

[25] Mucchetti G., Neviani E., Microbiologia e tecnologia lattiero-casearia. Qualità e sicurezza, Tecniche nuove, Milano, Italy, 2006.

[26] O’Cuinn G., Jennigs P.V., Fhaolain I.F., Booth M., Bacon C.L., McDonnel M., Wilkinson M., O'Callaghan M.D., Fitzgerald R.J., The contribution of the starter peptidases to flavour development in cheese, in: Cogan T.M., Fox P.F., Ross P. (Eds.), Proceedings of the 4th Cheese Symposium, Teagasc, University of Cork, Ireland, 1995, pp. 68-71.

[27] Panari G., L'acido lattico e l'acido piroglutammico nella maturazione del formaggio Parmigiano-Reggiano, Sci. Tecn. Latt.-Cas. 36 (1985) 98-109.

[28] Panari G., Reverberi P., Caroli A., Nocetti M., Pecorari M., Le variazione del profilo microbiologico del latte durante l'affioramento in diverse condizioni operative, Sci. Tecn. Latt.-Cas. 58 (2007) 83-93.

[29] Pereira C.I., Gomes E.O., Gomes A.M.P., Malcata F.X., Proteolysis in model Portuguese cheeses: effects of rennet and starter culture, Food Chem. 108 (2007) 862-868.

[30] Preininger M., Warmke R., Grosch W., Identification of the character impact flavour compounds of Swiss cheese by sensory studies of models, Z. Lebensm. Unters.-Forsch. 202 (1996) 30-34.

[31] Resmini P., Pellegrino L., Pazzaglia C., Hogenboom J.A., Gli amminoacidi liberi nella tipizzazione del formaggio Parmigiano-Reggiano ed in particolare nel prodotto grattugiato, Sci. Tecn. Latt.-Cas. 37 (1985) 557-592.

[32] Sandri S., Tosi F., Fossa E., Scotti C., Malacarne M., Andamento dei valori di $\mathrm{pH}$ misurati al centro della forma nelle prime ore successive alla fabbricazione del Parmigiano Reggiano: influenza di alcuni fattori tecnologici, Sci. Tecn. Latt.-Cas. 58 (2007) 17-28.

[33] Savijoki K., Ingmer H., Varmanen P., Proteolytic system of lactic acid bacteria, Appl. Microbiol. Biotechnol. 71 (2006) 394406 .

[34] Sheehan A., O'Cuinn G., FitzGerald R.J., Wilkinson M.G., Proteolytic enzyme activities in Cheddar cheese juice made using lactococcal starters of differing autolytic properties, J. Appl. Microbiol. 100 (2006) 893-901.

[35] Sheehan J.J., Fenelon M.A., Wilkinson M.G., McSweeney P.L.H., Effect of cook temperature on starter and non-starter lactic acid bacteria viability, cheese composition and ripening indices of a semi-hard cheese manufactured using thermophilic cultures, Int. Dairy J. 17 (2007) 704-716.

[36] Smit G., Smit B.A., Engels W.J.M., Flavour formation by lactic acid bacteria and biochemical flavour profiling of cheese products, FEMS Microbiol Rev. 29 (2005) 591610.

[37] Swaisgood H.E., Chemistry of milk proteins, in: Fox P.F. (Ed.), Developments in dairy chemistry, Vol. 1: Proteins, Elsevier Applied Science, London, UK, 1982, pp. 1-59.

[38] Takafuji S., Iwasaki T., Sasaki M., Tan P.S.T., Proteolytic enzymes of lactic acid bacteria, in: Charalambous G. (Ed.), Food Flavors: Generation, Analysis and Process Influence, Elsevier Science B.V., Amsterdam, The Netherlands, 1995, pp. 753-767.

[39] Valence F., Deutsch S.M., Richoux R., Gagnaire V., Lortal S., Autolysis and related proteolysis in Swiss cheese for two Lactobacillus helveticus strains, J. Dairy Res. 67 (2000) 261-271.

[40] Wilkinson M.G., Guinee T.P., O’Callaghan D.M., Fox P.F., Autolysis and proteolysis in different strains of starter bacteria during Cheddar cheese ripening, J. Dairy Res. 61 (1994) 249-262.

[41] Yvon M., Rijnen L., Cheese flavour formation by amino acid catabolism, Int. Dairy J. 11 (2001) 185-201. 